\title{
New Respiratory Viruses and the Elderly
}

\author{
Laura Jartti $^{1}$, Henriikka Langen ${ }^{1}$, Maria Söderlund-Venermo ${ }^{2}$, Tytti Vuorinen ${ }^{3}$, \\ Olli Ruuskanen ${ }^{4}$ and Tuomas Jartti ${ }^{*}, 4$
}

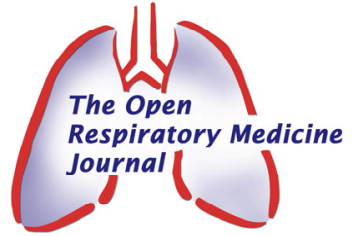

\author{
${ }^{I}$ Department of Geriatrics, Turku City Hospital, Turku, Finland \\ ${ }^{2}$ Department of Virology, University of Helsinki, Helsinki, Finland \\ ${ }^{3}$ Department of Virology, University of Turku, Turku, Finland \\ ${ }^{4}$ Department of Pediatrics, Turku University Hospital, Turku, Finland
}

\begin{abstract}
The diagnostics of respiratory viral infections has improved markedly during the last 15 years with the development of PCR techniques. Since 1997, several new respiratory viruses and their subgroups have been discovered: influenza A viruses $\mathrm{H} 5 \mathrm{~N} 1$ and $\mathrm{H} 1 \mathrm{~N} 1$, human metapneumovirus, coronaviruses SARS, NL63 and HKU1, human bocavirus, human rhinoviruses $\mathrm{C}$ and $\mathrm{D}$ and potential respiratory pathogens, the KI and WU polyomaviruses and the torque teno virus. The detection of previously known viruses has also improved. Currently, a viral cause of respiratory illness is almost exclusively identifiable in children, but in the elderly, the detection rates of a viral etiology are below $40 \%$, and this holds also true for exacerbations of chronic respiratory illnesses. The new viruses cause respiratory symptoms like the common cold, cough, bronchitis, bronchiolitis, exacerbations of asthma and chronic obstructive pulmonary disease and pneumonia. Acute respiratory failure may occur. These viruses are distributed throughout the globe and affect people of all ages. Data regarding these viruses and the elderly are scarce. This review introduces these new viruses and reviews their clinical significance, especially with regard to the elderly population.
\end{abstract}

Keywords: Bocavirus, coronavirus, elderly, influenza virus, metapneumovirus, polyomavirus, respiratory infection, torque teno virus.

\section{INTRODUCTION}

Life expectancy has increased globally over the past two centuries by almost 30 years [1] and only over the last five decades by almost 20 years. This very recent phenomenon emerged as a consequence of improvements in nutrition, hygiene, antimicrobial therapy and vaccinations $[2,3]$. The development of antiviral therapy, has, however, lagged behind. In the elderly, respiratory viral infections still cause significant morbidity and mortality: up to $40 \%$ of nonpneumonic lower respiratory illnesses have been linked to respiratory viral infection, and in USA alone, an estimated 54,000 annual deaths have been attributed to the influenza and respiratory syncytial viruses (RSV) [4-11].

A milestone in the diagnostics of respiratory viral infections was the discovery of influenza A virus in 1933 [12]. After the discovery of the coronaviruses in 1965, no new respiratory viruses or significant virus strains were identified in 32 years. The development of polymerase chain reaction (PCR) techniques in the 1990s initiated a new wave in viral diagnostics. The first avian flu epidemic in humans caused by influenza virus H5N1 struck in 1997 and alerted healthcare professionals by its severity [13]. In the same year, a virus family never seen in humans before, was identified: the anellovirus, the torque teno virus (TTV) as a signature virus, was found, but their link to human illnesses

*Address correspondence to this author at the Department of Pediatrics, Turku University Hospital, P.O. Box 52, 20520, Turku, Finland; Fax: +358 2313 1460; E-mail: tuomas.jartti@utu.fi has not been clarified [14-16]. In 2001, human metapneumovirus (MPV) was found followed by the discoveries of other new and significant respiratory viruses and virus strains: the coronaviruses SARS, NL63 and HKU1, the human bocavirus (HBoV), new human rhinovirus (HRV) strains (HRV-C and HRV-D), influenza A virus H1N1, and, as potential respiratory pathogens, the polyomaviruses KI and WU [17-28]. This review introduces these new viruses and reviews their clinical significance, especially with regard to the elderly population.

\section{SEARCH STRATEGY AND SELECTION CRITERIA}

We made systematical searches through the PubMed data base for articles published before March 5, 2011 and indexed with the following search terms: elderly; and influenza $\mathrm{H} 5 \mathrm{~N} 1$ virus; influenza $\mathrm{H} 1 \mathrm{~N} 1$ virus; metapneumovirus; coronavirus SARS, NL63, or HKU1; bocavirus; rhinovirus C or $\mathrm{D}$; polyomavirus $\mathrm{KI}$ or $\mathrm{WU}$; or torque teno virus. We reviewed only articles published in English.

\section{INFLUENZA VIRUSES H5N1 AND H1N1}

The most severe epidemics have been caused by the influenza A virus. In 1918-1919 the H1N1 virus pandemic resulted in an estimated 50 to 100 million deaths [29]. The mortality was surprisingly high among young adults. The most recent pandemics have usually been caused by the influenza A virus strain H1N1 and H3N2. The 2009 H1N1 virus was highly contagious from human to human [30,31]. In USA, the prevalence of H1N1-associated deaths was 12 deaths per 100000 population. Of these, only $9 \%$ occurred 
in persons aged ! 65 years [31]. Similarly, H5N1 which had its source in birds, has infected humans since 1997, and has, by March 2011, been associated with high mortality; of 528 patients with confirmed disease, 311 (59\%) have died [13, $30,32,33]$. The mortality rate associated with H5N1 infection has been $89 \%$ among children aged $<15$ years [32]. Elderly are often protected by pre-existing antibodies from previous illnesses, maybe even decades back [28, 30, 31]. On the other hand, the risk of severe illness is markedly increased by underlying medical conditions, especially chronic obstructive and other pulmonary diseases, immunosuppression, diabetes, obesity, or chronic heart conditions, which often accompany old age.

Influenza viruses typically cause mid-winter epidemics. The typical respiratory symptoms (cough, fever and sore throat), however, are poorly associated (43\%) with confirmed influenza illnesses in older adults [34, 35]. Hypoxia and chest radiographs consistent with the acute respiratory distress syndrome are characteristic of patients requiring intensive care [34]. If death occurs, it follows approximately more than one week after the onset of symptoms and mortality correlates with high virus titers. The cause of death is usually progressive cardiopulmonary failure. The influenza-related morbidity in the elderly is closely related to the prevalence of influenza virus infections among children (reservoir) [36]. The diagnosis is mainly based on antigen detection and PCR of respiratory specimen, but culture and serology are also available. Treatment options are neuraminidase inhibitors (oseltamivir and zanamivir) or adamantane derivatives (amantadine and rimantadine) [37]. Systemic corticosteroids are not effective and may, in fact, increase the risk of hospital-acquired pneumonia and superinfections [38]. Strain-specific influenza vaccination is usually available after 6 to 12 months after emergence of pandemic and has usually high immunogenicity among elderly subjects [39].

\section{HUMAN METAPNEUMOVIRUS}

Human metapneumovirus (MPV) causes upper and lower respiratory infections in patients of all ages, but mostly in children aged less than 5 years [17]. In healthy elderly subjects, MPV-infection is rare: one large study showed MPV RNA in nasal specimens in $1-2 \%$ of symptomatic and in $0-2 \%$ of asymptomatic elderly subjects [40]. In another study, MPV was only found in $2 \%$ of patients with acute exacerbation of chronic obstructive pulmonary disease (COPD) [41]. The prevalence of symptomatic MPV infection is higher (up to 4-7\%) in residents of long-term care facilities [40]. During outbreaks, up to $72 \%$ of elderly institutionalized persons may fall ill, 31\% may develop radiographically confirmed pneumonia and $50 \%$ may die $[42,43]$.

In adults and elderly, MPV typically causes influenzalike symptoms, such as rhinitis, cough and sore throat, but elderly subjects are more prone to lower respiratory symptoms such as wheezing and dyspnea [40, 42-44]. Overall, in the elderly, MPV infections are likely to be less severe than RSV infection and influenza [40]. The risk factors for severe illness, in addition to old age and institutionalization, include immunosuppression and chronic cardiopulmonary illness. MPV usually causes mid-winter epidemics. Asymptomatic MPV infections are rare. There seem to be two proposed genotypes, A and B, and several subgenotypes of MPV $[45,46]$, and thus it is unlikely that infection by either genotype of MPV confers crossprotective immunity. The diagnosis of MPV infections is based on PCR, but immune fluorescence assays are also available. Several vaccine candidates are being investigated $[47,48]$.

\section{SARS-ASSOCIATED CORONAVIRUS}

The pandemic caused by SARS-CoV $($ SARS $=$ severe acute respiratory syndrome) initiated in November 2002 in Guangdong province, China. It affected more than 8000 patients and caused 774 (approximately 10\%) deaths of all ages on 5 continents during an approximately 12 month period $[20,49,50]$. Infection by SARS-CoV was almost exclusively symptomatic resembling influenza with initial symptoms of fever, myalgia, malaise and chills or rigor [49]. Cough was common, but dyspnea was prominent only later in the course of the illness. Death was usually due to respiratory failure or a sepsis-related syndrome. Advanced age and co-morbidities increased markedly the risk of severe illness [50]. PCR tests have been rapidly developed and serology is also available $[19,20,49]$. No effective treatment is available, but interferons and ribavirin seem to inhibit virus replication [49]. Since the inflammation is part of the pathogenesis of this disease, corticosteroids may also be helpful if combined with antiviral medication [49]. Several new antivirals and vaccine candidates are being investigated.

\section{CORONAVIRUSES NL63 AND HKU1}

In addition to coronaviruses $229 \mathrm{E}$ and $\mathrm{OC} 43$, the new coronaviruses NL63 and HKU1 were identified in samples of patients with respiratory symptoms in 2005-2006 [18, 21, $22,44,51,52]$. Like other coronaviruses, NL63 and HKU1 can be detected in a small percentage of individuals of all ages [53]. These viruses have primarily been associated with mild upper respiratory tract infections, but severe lower respiratory tract infections have also been reported [51,52]. Diarrhea and abdominal pain may also occur, but symptoms and signs relate primarily to the respiratory tract [53-56]. Chronic underlying conditions and advanced age increase the susceptibility and disease severity of $\mathrm{CoV}$ infections, and mortality occurs $[44,53]$. In a study of community-acquired pneumonia, most of the HKU1-positive patients were old (median age 72 years) and had significant underlying diseases, especially of the respiratory and cardiovascular systems [18]. One study reported an outbreak of acute respiratory infection in a personal-care home, where $\mathrm{CoV}$ NL63 was identified in 7 of 8 patients aged $>50$ years [57]. One elderly patient died 5 days after the onset of $\mathrm{HCoV}$ NL63 infection. CoV-NL63 and CoV-HKU1 are distributed throughout the globe and throughout the year, although they usually peak in the winter time [54] and cause irregular epidemics every 2-3 years [58]. Since these viruses are difficult to culture, diagnostic tests other than PCR are not available. There is neither specific antiviral therapy nor vaccine available for $\mathrm{HCoV}$ infections [59].

\section{HUMAN BOCAVIRUS}

The prevalence of HBoV DNA in respiratory specimens ranges from $1.5-19 \%[23,60,61]$ and the most typical age 
for a primary $\mathrm{HBoV}$ infection is 6-48 months [62]. $\mathrm{HBoV}$ occurs world wide and throughout the year. $\mathrm{HBoV}$ has been associated with upper and with lower respiratory tract infections in children [62-66], but very little is known about $\mathrm{HBoV}$ infections among elderly people. HBoV has also been detected in the feces, in $1-9 \%$ of small children with or without gastrointestinal or respiratory symptoms [67-70] as well as in river and sewage water $[71,72]$, but whether it is a true enteric pathogen is not known.

Although $\mathrm{HBoV}$ infections are usually diagnosed with PCR, serological studies have shown that the mere presence of $\mathrm{HBoV}$ DNA in the respiratory tract is not proof of an acute primary $\mathrm{HBoV}$ infection [62, 73-75]. Studies on consecutive NPA samples have indeed shown that $\mathrm{HBoV}$ DNA can persist in the nasopharynx for several months [76, 77]. Among adults, over $94 \%$ have antibodies to $\mathrm{HBoV}$, indicating that they have encountered this virus during their lives $[78,79]$. The prevalence figure is high and shows that $\mathrm{HBoV}$ infections are extremely common. Only a limited number of HBoV DNA-positive adults have been reported, mainly among immunosuppressed subjects, an observation that is in line with the high seroprevalence of HBoV [80-84]. This age pattern was, however, interestingly contradicted by a Canadian study that did not find differences in the prevalence of $\mathrm{HBoV}$ among different age groups [85]. In adults, HBoV-DNA positivity seems to be associated with symptoms, and therefore, $\mathrm{HBoV}$ cannot be considered simply an innocent bystander virus [81, 83, 86]. Since the discovery of $\mathrm{HBoV}$, three other related bocaviruses (HBoV2, 3 and 4) have been identified in human stool samples [69, $87,88]$.

\section{HUMAN RHINOVIRUS, GROUPS C AND D}

Human rhinovirus, the common cold virus, is the most common respiratory pathogen in all age groups [12]. In the two last decades of the last millennium it was thought that two major genetic groups, A and B, and 99 HRV serotypes exist. Novel PCR-based techniques, however, have identified additionally two groups, $\mathrm{C}$ and $\mathrm{D}$, and possibly over 150 different HRV strains [24, 89, 90]. Moreover, PCR has markedly increased the detection rates of HRV infections. $\mathrm{HRV}$-infection is often associated with other pulmonary morbidity and is the most common virus (up to 60-70\%) associated with exacerbations of asthma of all ages and with COPD in adults and the elderly [91-96]. In long-term care facilities HRV may cause serious morbidity and mortality, and goes often unrecognized. Louie et al. (2005) reported an epidemic of respiratory illness in a long-term care facility, which caused a mortality rate of $21 \%$ (12/56 affected residents died) [10]. Seven of 13 respiratory specimens were culture-positive for rhinovirus [10]. Hicks et al. (2006) reported two nursing home outbreaks of respiratory illness that caused the death of 7 residents out of 294 (2.4\%). Of the 29 collected samples, $10(34 \%)$ were positive for rhinovirus [11]. There is an overall paucity of data on HRV-infections in the elderly.

Rhinovirus may in exceptional instances cause chronic lung infections which may have a duration of more than 12 months. Such prolonged infections may occur in immunocompromized subjects with lung transplants or hypogammaglobulinemia [96, 97]. The recently identified group C HRV appears to be related to high morbidity. This virus has circulated at a rate similar to those of the HRV-A and -B groups $[24,98,99]$ and is the cause for almost half of all HRV-associated hospitalizations in children [100, 101]. Different HRV strains circulate in the community throughout the year, but HRV epidemics typically peak in fall and spring. Diagnosis is based on PCR since these viruses are difficult to culture and serology is not feasible.

\section{KI AND WU POLYOMAVIRUSES}

In addition to the previously known polyomaviruses, BK and JC, seven new human polyomaviruses have been identified in rapid sequence in 2007-2011. Two of them, detected in the respiratory tract samples, have been named by the institutes where they have been found: KI (Karolinska Institute) polyomavirus (KIPyV) and WU (Washington University) polyomavirus (WUPyV) [25, 26]. Two have been named by the diseases in association with which they were detected, MCPyV from a skin cancer called Merkel-cell carcinoma and TSPyV from a skin disease called trichodysplasia spinulosa [102, 103]. The remaining three polyomaviruses were also detected in skin samples, and named by numbers, PyV6, 7 and 9 [104-106]. The prevalence of the respiratory KI- and WU-polyomaviruses is $2-7 \%$ in patients with respiratory symptoms $[25,26]$. Most patients with KI- or WUPyV DNA in their upper airways, are young children with symptoms of rhinitis, cough, bronchiolitis and even pneumonia. Serologic studies show seroprevalences of 50 to $80 \%$ for KI- and WUPyVs in healthy children and adults [108-110].

Data on the occurrence of these viruses in the elderly are lacking but are urgently needed, since PyVs are potentially oncogenic and can persist in human tissues [103, 111]. KIand WUPyV become reactivated at similar frequencies as the BK and JC viruses during immunosuppression [111, 112]. Diagnostics is based on PCR and serology [107, 109].

\section{TORQUE TENO VIRUS}

Torque teno virus DNA has been recovered from many tissues and secretions but whether this observation is causally related to clinical symptoms or not has not been demonstrated [14, 113-115]. TTV is possibly able to replicate in airway tissues $[116,117]$ and many other tissues e.g. liver and bone marrow [118]. The airways might be the primary route of transmission. TTV is very often detected in blood; the prevalence of TTV DNA in the blood of healthy individuals is approximately 70-90\% [119]. A single TTV infection may persist for years and cause chronic viremia [120-122]. Simultaneous infections by different TTV variants may also occur. TTV might also aggravate the symptoms caused by other respiratory viruses, or then TTV may be an indicator of the disease process as implied by the findings that TTV concentrations in nasal secretions or plasma have a positive correlation with markers of eosinophilic inflammation and a negative correlation with pulmonary function in asthma [15]. Also, the severity of bronchiectasis and of idiopathic pulmonary fibrosis correlate with high TTV concentrations [115]. The association between TTV and disease, could be based on a direct viral effect or be mediated by inflammatory processes that predispose to virus replication. Indeed, TTV replication kinetics have been used as a marker of immune 
reconstitution after suppression [123]. Although multiple TTV variants cause problems in detection, the diagnosis of TTV infections is based on PCR; serology will apparently not be developed in the near future [124].

\section{DIAGNOSIS}

Making a clinical diagnosis of a respiratory viral illness for elderly patients poses a challenge. The clinical picture is much more blurred in comparison to the typical upper respiratory infection, seen in children and young adults [35, 125-127]. Viral infections are usually due to reinfection, and elderly adults usually have some degree of immunity [128]. Because of pre-existing systemic and mucosal antibodies, elderly adults have probably lower amounts of respiratory secretions and lower viral loads as compared to children. Among elderly patients respiratory viral illness may accompany symptoms of lower respiratory tract involvement, pulmonary and cardiac failure, and nonspecific or atypical symptoms such as confusion, anorexia, dizziness, falls and lack of fever [125-128]. Finally, some elderly may also be unable to articulate their symptoms clearly, something they have in common with infants [128].

A further challenge to the diagnostics of viral illness is optimal sampling. Nasopharyngeal swabs, aspirates or washes are traditionally used in children but they are not well tolerated in older adults or older people. The best way and time to take samples for viral diagnostics are not known for the elderly. Although nasopharyngeal swab sampling is a sensitive and sufficient method for children [129, 130], this simplest sampling method may be difficult to apply to adults [131]. To obtain a sufficient sample and viral load, optimal sampling probably requires both nasopharyngeal and oropharyngeal sampling. Taking swab samples is probably the quickest way and causes the least discomfort while nasopharyngeal washing may collect more viruses [128, 131].

Of the conventional diagnostic methods available for these new respiratory viruses, serology is available for the influenza virus, MPV, HBoV and PyVs [62, 73, 109, 132, 133]. However, serology is not often practical in the acute phase. Of the other conventional methods, a rapid antigen detection test is available for the influenza virus. Some reports suggest that a rapid antigen detection test is relatively sensitive for detection of the influenza virus in elderly patients; during outbreaks up to $77 \%$ are detected by rapid antigen testing of culture positive samples [133, 134]. Other studies have reported much lower sensitivities (38-43\% compared with PCR) $[135,136]$. The sensitivity may be only $8-22 \%$ in patients ! 80 years of age [137]. Despite a poor sensitivity, the rapid antigen detection test is highly specific for detecting influenza viruses in the elderly

All new respiratory viruses can be diagnosed by sensitive PCR methods [44]. When diagnosing acute HBoV or SARS$\mathrm{CoV}$ infection, PCR needs to be complemented with serology. Currently, up to $85-95 \%$ of all viruses in respiratory samples of children with respiratory symptoms may be detected [61, 138-142]. PCR is the best choice also for the elderly since it is the most sensitive method for detection of viruses in this age group as well [136, 143-147], although the detection rates, probably due to the difficulties in sampling, decline with age. The detection rates among elderly patients have remained below $40 \%$ even in exacerbations of chronic pulmonary disease [91, 92, 95, 148] and viral pneumonia [149]. The rates in the intermediate age groups, i.e., adults with exacerbations of COPD or asthma have been up to $64 \%$ [150-152]. The actual prevalences of the new viruses among the elderly population are not known $[5,7,10,11,148,153]$.

The interpretation of positive PCR results is complicated by multiple co-existing viruses especially in symptomatic children (up to $43 \%$ ) and by high virus detection rates in asymptomatic subjects (up to $40-68 \%$ in young children) $[139,154-157]$. In a review of the literature that goes back to 1965 and stretches to 2008 , the prevalence of viruses in 15000 samples from asymptomatic subjects was higher by PCR than by conventional methods [158]. This casts some doubt on the clinical significance of PCR-positive viral findings overall. Several studies have, on the other hand, demonstrated that positive PCR results are clinically relevant at least as far as HRV is concerned. Identification of HRV correlates with respiratory symptoms, dual HRV infections are rare and overall, the prevalence of recurrent or persistent respiratory viral infections (excluding TTV and $\mathrm{HBoV}$ ) is low (3-4\%) [96, 158-160]. Positive findings with PCR correlate with systemic or local immune responses in children and in adults [161-163]. These findings, which mainly apply to HRV and not to HBoV, suggest that HRVPCR positivity probably reflects a true, current respiratory infection with or without symptoms, rather than residual nucleic acids from some other distant infection. Of course, any findings in upper airway samples do not necessarily reflect the situation in lower airways [164]. Multiple PCR analyses of single samples (multiplex PCR) may sound attractive, but the sensitivity for identification of individual viruses may be lost compared to single virus PCR [165]. Of note, most of these data are from studies on children and adults, and data on new respiratory viruses in the elderly are scarce.

\section{IMMUNOSENESCENCE}

The term immunosenescence describes the deleterious age-associated changes in the immune system that render elderly individuals susceptible to infectious disease and increases morbidity and mortality $[3,166]$. With age, all components of immunity are affected, but the $\mathrm{T}$ cells are the most susceptible [167]. Although the adaptive function of immunity appears to be more seriously affected than the innate immune system, the increased susceptibility to lower respiratory tract viral infections relates particularly to defective innate immunity $[163,168]$. The weakening immune responses could be linked to the over-all long-term poor outcome in the elderly [166]. Immunosenescence is a multifactorial process and is associated with thymic involution, chronic antigenic stimulation (predominantly attributable to persistent infections), signal transduction changes in immune cells, and protein-energy malnutrition [169]. There is a paucity of accurate data on the link between the causes of death of elderly and the age-associated changes in the immune system.

\section{TREATMENT}

With the exception of the influenza viruses, there are no specific treatments or vaccines available to combat the new 
viruses. In this sense, there is no clinical need for a viral diagnosis. Viral detection may still have practical importance with regard to isolating practices of infected patients in hospitals or in long-term care settings to prevent transmission of disease [128] and for proper supportive treatment, including avoidance of unnecessary antibiotic treatments [146].

An increased susceptibility to viral infections could be a marker of a pulmonary inflammatory processes, and indicate a need for intensified treatment of chronic pulmonary illness. For example, TTV and AdV infections are associated with a chronic inflammatory state of the lungs $[15,170-173]$. In children, there is a link between susceptibility to HRVinduced wheezing and the development of asthma [174-178], and in adults, HRV is the most important trigger of exacerbations of COPD [91, 95].

Current knowledge on bacterial-viral coinfections in the elderly is very limited. In community-acquired pneumonia of adults, there is evidence of mixed viral-bacterial infection in up to $15 \%$ of cases and in children up to $45 \%$ of cases [179]. The most frequent combinations have been Streptococcus pneumoniae with influenza A virus or HRV. Bacterial and viral infections may act deleteriously through synergistic mechanisms. There may be destruction of the respiratory epithelium by the viral infection, which may increase bacterial adhesion; virus-induced immunosuppression may cause bacterial superinfections; and the inflammatory response to viral infection may up-regulate the expression of molecules that are suitable for bacteria as receptors [180].

Vaccines are being developed against these new viruses. The most promising preclinical results have been reported for vaccine candidates for MPV and SARS-CoV, but their efficacy have not been studied in humans [181, 182].

\section{CONCLUSIONS}

The new respiratory viruses or viral strains include influenza A virus H5N1 and H1N1, MPV, SARS-, NL63and HKU1-CoV, HBoV, HRV-C and $-\mathrm{D}$ and the possible respiratory pathogens, KI- and, WU-PyV and TTV $[13,14$, 17-28]. All these new viruses are distributed throughout the globe and affect people of all ages, but data on these viruses and the elderly are scarce. These new viral infections can be diagnosed by sensitive PCR methods. The viruses may be detectable in the airways for varying periods of time also after the acute phase and this leads to a diagnosis of several concomitant viruses. The classical predisposing factors to viral infections include advanced age, chronic illnesses and poor immune responses. The elderly often have partial immunity and chronic illnesses; these circumstances modify their responses to viruses and thus respiratory viral infections may manifest themselves as atypical symptoms or as exacerbation of chronic illnesses. Serious outbreaks have been reported in long-term care facilities. Vaccination is the most effective way to prevent serious disease, but it is only available for the influenza virus. Virus-specific treatment is also available only for the influenza virus. Early identification of a viral pathogen through improved viral diagnostics is crucial for successful treatment of viral illnesses. Preventive measures are also important, such as vaccinations, hand-washing and isolation of the affected individuals in hospitals and long-term care facilities. The ultimate clinical significance of the new respiratory viruses is still poorly unknown in the elderly population but probably these infections are greatly underestimated.

\section{ACKNOWLEDGEMENTS}

Supported by the EVO funds by Turku City Hospital, Turku, and the Academy of Finland, Helsinki, both in Finland.

\section{REFERENCES}

[1] Christensen K, Doblhammer G, Rau R, Vaupel JW. Ageing populations: the challenges ahead. Lancet 2009; 374: 1196-208.

[2] World Health Organization. The European Health Report 2002. WHO Regional Publications, European Series No. 97. Geneva, Switzerland: World Health Organization 2002.

[3] Pawelec G, Derhovanessian E, Larbi A, Strindhall J, Wikby A. Cytomegalovirus and human immunosenescence. Rev Med Virol 2009; 19: 47-56.

[4] Kobashi Y, Okimoto N, Matsushima T, Soejima R. Clinical analysis of community-acquired pneumonia in the elderly. Intern Med 2001; 40: 703-7.

[5] Falsey AR, Walsh EE, Hayden FG. Rhinovirus and coronavirus infection-associated hospitalizations among older adults. J Infect Dis 2002; 185: 1338-41.

[6] Thompson WW, Shay DK, Weintraub E, et al. Mortality associated with influenza and respiratory syncytial virus in the United States. JAMA 2003; 289: 179-86.

[7] Lieberman D, Lieberman D, Ben-Yaakov M, et al. Infectious aetiologies in elderly patients hospitalised with non-pneumonic lower respiratory tract infection. Age Ageing 2003; 32: 95-101.

[8] Flamaing J, Engelmann I, Joosten E, Van Ranst M, Verhaegen J, Peetermans WE. Viral lower respiratory tract infection in the elderly: a prospective in-hospital study. Eur J Clin Microbiol Infect Dis $2003 ; 22: 720-5$.

[9] Thompson WW, Shay DK, Weintraub E, et al. Influenza-associated hospitalizations in the United States. JAMA 2004; 292: 1333-40.

[10] Louie JK, Yagi S, Nelson FA, et al. Rhinovirus outbreak in a long term care facility for elderly persons associated with unusually high mortality. Clin Infect Dis 2005; 41: 262-5.

[11] Hicks LA, Shepard CW, Britz PH, et al. Two outbreaks of severe respiratory disease in nursing homes associated with rhinovirus. J Am Geriatr Soc 2006; 54: 284-9.

[12] Knipe DM, Howley PM, Ed. Fields Virology, $5^{\text {th }}$ ed. Philadelphia, PA: Lippincott Williams \& Wilkins 2007.

[13] Centers for Disease Control and Prevention (CDC). Isolation of avian influenza A(H5N1) viruses from humans--Hong Kong, MayDecember 1997. MMWR Morb Mortal Wkly Rep 1997; 46: 12047 .

[14] Nishizawa T, Okamoto H, Konishi K, Yoshizawa H, Miyakawa Y, Mayumi M. A novel DNA virus (TTV) associated with elevated transaminase levels in posttransfusion hepatitis of unknown etiology. Biochem Biophys Res Commun 1997; 241: 92-7.

[15] Hino S, Miyata H. Torque teno virus (TTV): current status. Rev Med Virol 2007; 17: 45-57.

[16] Kakkola L. Human Torque teno virus: epidemiology, cell biology and immunology. Helsinki University Biomedical Dissertations. No. 103. Helsinki: University Printing House 2008.

[17] van den Hoogen BG, de Jong JC, Groen J, Kuiken T, de Groot R, Fouchier RA, Osterhaus AD. A newly discovered human pneumovirus isolated from young children with respiratory tract disease. Nat Med 2001; 7: 719-24.

[18] Woo PC, Lau SK, Chu CM, et al. Characterization and complete genome sequence of a novel coronavirus, coronavirus HKU1, from patients with pneumonia. J Virol 2005; 79: 884-95.

[19] Drosten C, Günther S, Preiser W, et al. Identification of a novel coronavirus in patients with severe acute respiratory syndrome. $\mathrm{N}$ Engl J Med 2003; 348: 1967-76.

[20] Ksiazek TG, Erdman D, Goldsmith CS, et al. A novel coronavirus associated with severe acute respiratory syndrome. N Engl J Med 2003; 348: 1953-66.

[21] van der Hoek L, Pyrc K, Jebbink MF, et al. Identification of a new human coronavirus. Nat Med 2004; 10: 368-73. 
[22] Fouchier RA, Hartwig NG, Bestebroer TM, et al. A previously undescribed coronavirus associated with respiratory disease in humans. Proc Natl Acad Sci USA 2004; 101: 6212-6.

[23] Allander T, Tammi MT, Eriksson M, Bjerkner A, TiveljungLindell A, Andersson B. Cloning of a human parvovirus by molecular screening of respiratory tract samples. Proc Natl Acad Sci USA 2005; 102: 12801-5.

[24] Lee WM, Kiesner C, Pappas T, Lee I, et al. A diverse group of previously unrecognized human rhinoviruses are common causes of respiratory illnesses in infants. PLoS One 2007; 2: e966.

[25] Allander T, Andreasson K, Gupta S, et al. Identification of a third human polyomavirus. J Virol 2007; 81: 4130-6.

[26] Gaynor AM, Nissen MD, Whiley DM, et al. Identification of a novel polyomavirus from patients with acute respiratory tract infections. PLoS Pathog 2007; 3: 595-604.

[27] Centers for Disease Control and Prevention (CDC). Swine influenza A (H1N1) infection in two children---southern California, March--April 2009. MMWR 2009; 58: 400-2.

[28] Centers for Disease Control and Prevention (CDC). Outbreaks of 2009 pandemic influenza A (H1N1) among long-term-care facility residents - three states, 2009. MMWR Morb Mortal Wkly Rep 2010; 59: 74-7.

[29] Zimmer SM, Burke DS. Historical perspective-emergence of influenza A (H1N1) viruses. N Engl J Med 2009; 361: 279-85.

[30] Subbarao K, Klimov A, Katz J, et al. Characterization of an avian influenza A (H5N1) virus isolated from a child with a fatal respiratory illness. Science 1998; 279: 393-6.

[31] Fowlkes AL, Arguin P, Biggerstaff MS, et al. Epidemiology of 2009 Pandemic Influenza A (H1N1) Deaths in the United States, April-July 2009. Clin Infect Dis 2011; 52(Suppl 1): S60-8.

[32] Beigel JH, Farrar J, Han AM, et al. Avian influenza A (H5N1) infection in humans. N Engl J Med 2005; 353: 1374-85.

[33] World Health Organization (WHO). Epidemic and Pandemic Alert and Response (EPR). Cumulative Number of Confirmed Human Cases of Avian Influenza A/(H5N1) Reported to WHO. http://www.who.int/csr/disease/avian_influenza/country/cases_tabl e_2011_03_02/en/index.html

[34] Sullivan SJ, Jacobson RM, Dowdle WR, Poland GA. 2009 H1N1 influenza. Mayo Clin Proc 2010; 85: 64-76.

[35] Babcock HM, Merz LR, Dubberke ER, Fraser VJ. Case-control study of clinical features of influenza in hospitalized patients. Infect Control Hosp Epidemiol 2008; 29: 921-6.

[36] Reichert TA, Sugaya N, Fedson DS, Glezen WP, Simonsen L, Tashiro M. The Japanese experience with vaccinating schoolchildren against influenza. N Engl J Med 2001; 344: 889-96.

[37] Moscona A. Neuraminidase inhibitors for influenza. N Engl J Med 2005; 353: 1363-73.

[38] Martin-Loeches I, Lisboa T, Rhodes A, et al. Use of early corticosteroid therapy on ICU admission in patients affected by severe pandemic $(\mathrm{H} 1 \mathrm{~N} 1)$ influenza $\mathrm{A}$ infection. Intensive Care Med 2011;37: 272-83.

[39] Leroux-Roels I, Van der Wielen M, Kafeja F, et al. Humoral and cellular immune responses to split-virion $\mathrm{H} 5 \mathrm{~N} 1$ influenza vaccine in young and elderly adults. Vaccine 2009; 27: 6918-25.

[40] Falsey AR, Erdman D, Anderson LJ, Walsh EE. Human metapneumovirus infections in young and elderly adults. J Infect Dis 2003 ; 187 : 785-90.

[41] Rohde G, Borg I, Arinir U, et al. Relevance of human metapneumovirus in exacerbations of COPD. Respir Res 2005; 6: 150 .

[42] Boivin G, De Serres G, Hamelin ME, et al. An outbreak of severe respiratory tract infection due to human metapneumovirus in a long-term care facility. Clin Infect Dis 2007; 44: 1152-8.

[43] Louie JK, Schnurr DP, Pan CY, et al. A summer outbreak of human metapneumovirus infection in a long-term-care facility. J Infect Dis 2007; 196: 705-8.

[44] Sloots TP, Whiley DM, Lambert SB, Nissen MD. Emerging respiratory agents: new viruses for old diseases? J Clin Virol 2008; 42: 233-43.

[45] Biacchesi S, Skiadopoulos MH, Boivin G, et al. Genetic diversity between human metapneumovirus subgroups. Virology 2003; 315: $1-9$.

[46] Arnott A, Vong S, Sek M, et al. Genetic variability of human metapneumovirus amongst an all ages population in Cambodia between 2007 and 2009. Infect Genet Evol 2011 [Epub ahead of print].
[47] Ryder AB, Tollefson SJ, Podsiad AB, Johnson JE, Williams JV. Soluble recombinant human metapneumovirus $G$ protein is immunogenic but not protective. Vaccine 2010; 28: 4145-52.

[48] Mok H, Tollefson SJ, Podsiad AB, et al. An alphavirus repliconbased human metapneumovirus vaccine is immunogenic and protective in mice and cotton rats. J Virol 2008; 82: 11410-8.

[49] Peiris JS, Yuen KY, Osterhaus AD, Stöhr K. The severe acute respiratory syndrome. N Engl J Med 2003; 349: 2431-41.

[50] Sung JJ, Wu A, Joynt GM, et al. Severe acute respiratory syndrome: report of treatment and outcome after a major outbreak. Thorax 2004; 59: 414-20.

[51] Tyrrell DAJ, Bynoe ML. Cultivation of a novel common cold virus in organ cultures. BMJ 1965; 1: 1467-70.

[52] McIntosh K, Kapikian AZ, Hardison KA, Hartley JW, Chanock RM. Antigenic relationships among the coronaviruses of man and between human and animal coronaviruses. J Immunol 1969; 102: $1109-18$

[53] Pyrc K, Berkhout B, van der Hoek L. The novel Human Coronaviruses NL63 and HKU1. J Virol 2007; 81: 3051-7.

[54] Esper F, Weibel C, Ferguson D, Landry ML, Kahn JS. Evidence of a novel human coronavirus that is associated with respiratory tract disease in infants and young children. J Infect Dis 2005; 191: 4928.

[55] Vabret A, Mourez T, Dina J, et al. Human coronavirus NL63, France. Emerg Infect Dis 2005; 11: 1225-9.

[56] Splete H. Coronavirus adds respiratory symptoms. Pediatric News 2009; 42: 12-13.

[57] Bastien N, Anderson K, Hart L, et al. Human coronavirus NL63 infection in Canada. J Infect Dis 2005; 191: 503-6.

[58] Kahn, JS. The widening scope of coronaviruses. Curr Opin Pediatr 2006; 18: 42-7.

[59] Nichols WG, Peck Campbell AJ, Boeckh M. Respiratory viruses other than influenza virus: impact and therapeutic advances. Clin Microbiol Rev 2008; 21: 274-90.

[60] Bastien N, Chui N, Robinson JL, et al. Detection of human bocavirus in Canadian children in a 1-year study. J Clin Microbiol 2007; 45: 610-3.

[61] Allander T, Jartti T, Gupta S, et al. Human bocavirus and acute wheezing in children. Clin Infect Dis 2007; 44: 904-10.

[62] Söderlund-Venermo M, Lahtinen A, Jartti $\mathrm{T}$, et al. Clinical assessment and improved diagnosis of bocavirus-induced wheezing in children, Finland. Emerg Infect Dis 2009; 15: 1423-30.

[63] Kesebir D, Vazquez M, Weibel C, et al. Human bocavirus infection in young children in the United States: molecular epidemiological profile and clinical characteristics of a newly emerging respiratory virus. J Infect Dis 2006; 194: 1276-82.

[64] Maggi F, Andreoli E, Pifferi M, Meschi S, Rocchi J, Bendinelli M. Human bocavirus in Italian patients with respiratory diseases. J Clin Virol 2007; 38: 321-5.

[65] Fry AM, Lu X, Chittaganpitch M, et al. Human bocavirus: a novel parvovirus epidemiologically associated with pneumonia requiring hospitalization in Thailand. J Infect Dis 2007; 195: 1038-45.

[66] Lahti E, Peltola V, Waris M, et al. Induced sputum in the diagnosis of childhood community-acquired pneumonia. Thorax 2009; 64: 252-7.

[67] Vicente D, Cilla G, Montes M, Pérez-Yarza EG, Pérez-Trallero E. Human bocavirus, a respiratory and enteric virus. Emerg Infect Dis 2007; 13: 636-7.

[68] Lee JI, Chung JY, Han TH, Song MO, Hwang ES. Detection of human bocavirus in children hospitalized because of acute gastroenteritis. J Infect Dis 2007; 196: 994-7.

[69] Arthur JL, Higgins GD, Davidson GP, Givney RC, Ratcliff RM. A novel bocavirus associated with acute gastroenteritis in Australian children. PLoS Pathog 2009; 5: e1000391.

[70] Cheng WX, Jin Y, Duan ZJ, et al. Human bocavirus in children hospitalized for acute gastroenteritis: a case-control study. Clin Infect Dis 2008; 47: 161-7.

[71] Hamza IA, Jurzik L, Wilhelm M, Uberla K. Detection and quantification of human bocavirus in river water. J Gen Virol 2009; 90: 2634-7.

[72] Blinkova O, Rosario K, Li L, et al. Frequent detection of highly diverse variants of cardiovirus, cosavirus, bocavirus, and circovirus in sewage samples collected in the United States. J Clin Microbiol 2009; 47: 3507-13.

[73] Kantola K, Hedman L, Allander T, et al. Serodiagnosis of human bocavirus infections. Clin Infect Dis 2008; 46: 540-6. 
[74] Hedman L, Söderlund-Venermo M, Jartti T, Ruuskanen O, Hedman K. Dating of human bocavirus infection with proteindenaturing IgG-avidity assays-Secondary immune activations are ubiquitous in immunocompetent adults. J Clin Virol 2010; 48: 448 .

[75] Don M, Söderlund-Venermo M, Valent F, et al. Serologically verified human bocavirus pneumonia in children. Pediatr Pulmonol 2010; 45: 120-6.

[76] von Linstow ML, Høgh M, Høgh B, et al. Clinical and epidemiologic characteristics of human bocavirus in Danish infants: results from a prospective birth cohort study. Pediatr Infect Dis J 2008; 27: 897-902.

[77] Blessing K, Neske F, Herre U, Kreth HW, Weissbrich B. Prolonged detection of human bocavirus DNA in nasopharyngeal aspirates of children with respiratory tract disease. Pediatr Infect Dis J 2009; 28: 1018-9.

[78] Lindner J, Karalar L, Zehentmeier S, et al. Humoral immune response against human bocavirus VP2 virus-like particles. Viral Immunol 2008; 21: 443-9.

[79] Kahn JS, Kesebir D, Cotmore SF, et al. Seroepidemiology of human bocavirus defined using recombinant virus-like particles. J Infect Dis 2008; 198: 41-50.

[80] Longtin J, Bastien M, Gilca R, et al. Human bocavirus infections in hospitalized children and adults. Emerg Infect Dis 2008; 14: 217 21.

[81] Chow BD, Huang YT, Esper FP. Evidence of human bocavirus circulating in children and adults, Cleveland, Ohio. J Clin Virol 2008; 43: 302-6

[82] Ringshausen FC, Tan AY, Allander T, et al. Frequency and clinical relevance of human bocavirus infection in acute exacerbations of chronic obstructive pulmonary disease. Int $\mathrm{J}$ Chron Obstruct Pulmon Dis 2009; 4: 111-7.

[83] Costa C, Bergallo M, Cavallo R. Detection of Human Bocavirus in bronchoalveolar lavage from Italian adult patients. J Clin Virol 2009; 45: 81-2.

[84] Garbino J, Soccal PM, Aubert JD, et al. Respiratory viruses in bronchoalveolar lavage: a hospital-based cohort study in adults. Thorax 2009; 64: 399-404.

[85] Bastien N, Brandt K, Dust K, Ward D, Li Y. Human Bocavirus infection, Canada. Emerg Infect Dis 2006; 12: 848-50.

[86] Miyakis S, van Hal SJ, Barratt J, Stark D, Marriott D, Harkness J. Absence of human Bocavirus in bronchoalveolar lavage fluid of lung transplant patients. J Clin Virol 2009; 44: 179-80.

[87] Kapoor A, Slikas E, Simmonds P, et al. A newly identified bocavirus species in human stool. J Infect Dis 2009; 199: 196-200.

[88] Kapoor A, Simmonds P, Slikas E, et al. Human bocaviruses are highly diverse, dispersed, recombination prone, and prevalent in enteric infections. J Infect Dis 2010; 201: 1633-43.

[89] Palmenberg AC, Spiro D, Kuzmickas R, et al. Sequencing and analyses of all known human rhinovirus genomes reveal structure and evolution. Science 2009; 324: 55-9.

[90] Simmonds P, McIntyre C, Savolainen-Kopra C, Tapparel C, Mackay IM, Hovi T. Proposals for the classification of human rhinovirus species $\mathrm{C}$ into genotypically assigned types. J Gen Virol 2010; 91: 2409-19.

[91] Mallia P, Johnston SL. How viral infections cause exacerbation of airway diseases? Chest 2006; 130: 1203-10.

[92] Mallia P, Johnston SL. Influenza infection and COPD. Int J Chron Obstruct Pulmon Dis 2007; 2: 55-64.

[93] Sethi S, Mallia P, Johnston SL. New paradigms in the pathogenesis of chronic obstructive pulmonary disease II. Proc Am Thorac Soc 2009; 6: 532-4.

[94] Jartti T, Lehtinen P, Vuorinen T, et al. Respiratory picornaviruses and respiratory syncytial virus as causative agents of acute expiratory wheezing in children. Emerg Infect Dis 2004; 10: 1095101.

[95] Camargo CA Jr, Ginde AA, Clark S, Cartwright CP, Falsey AR, Niewoehner DE. Viral pathogens in acute exacerbations of chronic obstructive pulmonary disease. Intern Emerg Med 2008; 3: 355-9.

[96] Kaiser L, Aubert JD, Pache JC, et al. Chronic rhinoviral infection in lung transplant recipients. Am J Respir Crit Care Med 2006; 174: 1392-9.

[97] Kainulainen L, Vuorinen T, Rantakokko-Jalava K, Osterback R, Ruuskanen O. Recurrent and persistent respiratory tract viral infections in patients with primary hypogammaglobulinemia. J Allergy Clin Immunol 2010; 126: 120-6.
[98] Huang T, Wang W, Bessaud M, et al. Evidence of recombination and genetic diversity in human rhinoviruses in children with acute respiratory infection. PLoS One 2009; 4: e6355.

[99] Piralla A, Rovida F, Campanini G, et al. Clinical severity and molecular typing of human rhinovirus $\mathrm{C}$ strains during a fall outbreak affecting hospitalized patients. J Clin Virol 2009; 45: 3117.

[100] Miller EK, Edwards KM, Weinberg GA, et al. A novel group of rhinoviruses is associated with asthma hospitalizations. J Allergy Clin Immunol 2009; 123: 98-104.

[101] Peltola V, Jartti T, Putto-Laurila A, et al. Rhinovirus infections in children: a retrospective and prospective hospital-based study. J Med Virol 2009; 81: 1831-8.

[102] Feng H, Shuda M, Chang Y, Moore PS. Clonal integration of a polyomavirus in human Merkel cell carcinoma. Science 2008; 319: 1096-100.

[103] van der Meijden E, Janssens RW, Lauber C, Bouwes Bavinck JN, Gorbalenya AE, Feltkamp MC. Discovery of a new human polyomavirus associated with trichodysplasia spinulosa in an immunocompromized patient. PLoS Pathog 2010; 6: e1001024.

[104] Schowalter RM, Pastrana DV, Pumphrey KA, Moyer AL, Buck CB. Merkel cell polyomavirus and two previously unknown polyomaviruses are chronically shed from human skin. Cell Host Microb 2010; 7: 509-15.

[105] Scuda N, Hofmann J, Calvignac-Spencer S, et al. A novel human polyomavirus closely related to the African green monkey-derived lymphotropic polyomavirus (LPV). J Virol 2011; 85: 4586-90.

[106] Kantola K, Sadeghi M, Lahtinen A, et al. Merkel cell polyomavirus DNA in tumor-free tonsillar tissues and upper respiratory tract samples: implications for respiratory transmission and latency. J Clin Virol 2009; 45: 292-5.

[107] Touzé A, Gaitan J, Arnold F, et al. Generation of Merkel cell polyomavirus (MCV)-like particles and their application to detection of MCV antibodies. J Clin Microbiol 2010; 48: 1767-70.

[108] Kantola K, Sadeghi M, Ewald MJ, et al. Expression and serological characterization of polyomavirus WUPyV and KIPyV structural proteins. Viral Immunol 2010; 23: 385-93.

[109] Neske F, Prifert C, Scheiner B, et al. High prevalence of antibodies against polyomavirus $\mathrm{WU}$, polyomavirus $\mathrm{KI}$, and human bocavirus in German blood donors. BMC Infect Dis 2010; 10: 215.

[110] zur Hausen H. Novel human polyomaviruses--re-emergence of a well known virus family as possible human carcinogens. Int $\mathrm{J}$ Cancer 2008; 123: 247-50.

[111] Sharp CP, Norja P, Anthony I, Bell JE, Simmonds P. Reactivation and mutation of newly discovered WU, KI, and Merkel cell carcinoma polyomaviruses in immunosuppressed individuals. J Infect Dis 2009; 199: 398-404.

[112] Tyler KL. Emerging viral infections of the central nervous system: part 1. Arch Neurol 2009; 66: 939-48.

[113] Maggi F, Pifferi M, Fornai C, et al. TT virus in the nasal secretions of children with acute respiratory diseases: relations to viremia and disease severity. J Virol 2003; 77: 2418-25.

[114] Pifferi M, Maggi F, Andreoli E, et al. Associations between nasal torquetenovirus load and spirometric indices in children with asthma. J Infect Dis 2005; 192: 1141-8.

[115] Pifferi M, Maggi F, Caramella D, et al. High torquetenovirus loads are correlated with bronchiectasis and peripheral airflow limitation in children. Pediatr Infect Dis J 2006; 25: 804-8.

[116] Deng X, Terunuma H, Handema R, et al. Higher prevalence and viral load of TT virus in saliva than in the corresponding serum: another possible transmission route and replication site of TT virus. J Med Virol 2000; 62: 531-7.

[117] Bando M, Ohno S, Oshikawa K, Takahashi M, Okamoto H, Sugiyama Y. Infection of TT virus in patients with idiopathic pulmonary fibrosis. Respir Med 2001; 95: 935-42.

[118] Kakkola L, Hedman K, Qiu J, Pintel D, Söderlund-Venermo M. Replication of and protein synthesis by TT viruses. Curr Top Microbiol Immunol 2009; 331: 53-64

[119] Kakkola L, Hedman K, Vanrobaeys H, Hedman L, SöderlundVenermo M. Cloning and sequencing of TT virus genotype 6 and expression of antigenic open reading frame 2 proteins. J Gen Virol 2002; 83: 979-90.

[120] Bendinelli M, Pistello M, Maggi F, Fornai C, Freer G, Vatteroni ML. Molecular properties, biology, and clinical implications of TT virus, a recently identified widespread infectious agent of humans. Clin Microbiol Rev 2001; 14: 98-113. 
[121] Biagini P, de Micco P, de Lamballerie X. Identification of a third member of the Anellovirus genus ("small anellovirus") in French blood donors. Arch Virol 2006; 151: 405-8.

[122] Ninomiya M, Takahashi M, Shimosegawa T, Okamoto H. Analysis of the entire genomes of fifteen torque teno midi virus variants classifiable into a third group of genus Anellovirus. Arch Virol 2007; 152: 1961-75

[123] Focosi D, Maggi F, Albani M, et al. Torquetenovirus viremia kinetics after autologous stem cell transplantation are predictable and may serve as a surrogate marker of functional immune reconstitution. J Clin Virol 2010; 47: 189-92.

[124] Kakkola L, Bondén H, Hedman L, et al. Expression of all six human Torque teno virus (TTV) proteins in bacteria and in insect cells, and analysis of their IgG responses. Virology 2008; 382: 1829.

[125] Govaert TM, Dinant GJ, Aretz K, Knottnerus JA. The predictive value of influenza symptomatology in elderly people. Fam Pract 1998; $15: 16-22$

[126] Matsuno O, Kataoka $\mathrm{H}$, Takenaka $\mathrm{R}$, et al. Influence of age on symptoms and laboratory findings at presentation in patients with influenza-associated pneumonia. Arch Gerontol Geriatr 2009; 49: $322-5$.

[127] Neuzil KM, O'Connor TZ, Gorse GJ, Nichol KL. Recognizing influenza in older patients with chronic obstructive pulmonary disease who have received influenza vaccine. Clin Infect Dis 2003; 36: 169-74.

[128] Talbot HK, Falsey AR. The diagnosis of viral respiratory disease in older adults. Clin Infect Dis 2010; 50: 747-51.

[129] Heikkinen T, Salmi AA, Ruuskanen O. Comparative study of nasopharyngeal aspirate and nasal swab specimens for detection of influenza. Br Med J 2001; 322: 138

[130] Heikkinen T, Marttila J, Salmi AA, Ruuskanen O. Nasal swab versus nasopharyngeal aspirate for isolation of respiratory viruses. J Clin Microbiol 2002; 40: 4337-9.

[131] Lieberman D, Shimoni A, Keren-Naus A, Steinberg R, ShemerAvni Y. Identification of respiratory viruses in adults: nasopharyngeal versus oropharyngeal sampling. J Clin Microbiol 2009; 47: 3439-43.

[132] Vinh DC, Newby D, Charest H, McDonald J. Evaluation of a commercial direct fluorescent-antibody assay for human metapneumovirus in respiratory specimens. J Clin Microbiol 2008; 46: $1840-1$.

[133] Rahman M, Kieke BA, Vandermause MF, Mitchell PD, Greenlee RT, Belongia EA. Performance of Directigen flu A+B enzyme immunoassay and direct fluorescent assay for detection of influenza infection during the 2004-2005 season. Diagn Microbiol Infect Dis 2007; 58: 413-8.

[134] Monto AS, Rotthoff J, Teich E, et al. Detection and control of influenza outbreaks in well-vaccinated nursing home populations. Clin Infect Dis 2004; 39: 459-64.

[135] Gooskens J, Swaan CM, Claas EC, Kroes AC. Rapid molecular detection of influenza outbreaks in nursing homes. J Clin Virol 2008; 41: 7-12.

[136] Steininger C, Redlberger M, Graninger W, Kundi M, PopowKraupp T. Near-patient assays for diagnosis of influenza virus infection in adult patients. Clin Microbiol Infect 2009; 15: 267-73.

[137] Walsh EE, Cox C, Falsey AR. Clinical features of influenza A virus infection in older hospitalized persons. J Am Geriatr Soc 2002; 50: 1498-503.

[138] Johnston SL, Pattemore PK, Sanderson G, et al. Community study of role of viral infections in exacerbations of asthma in 9-11 year old children. Br Med J 1995; 310: 1225-9.

[139] Rakes GP, Arruda E, Ingram JM, et al. Rhinovirus and respiratory syncytial virus in wheezing children requiring emergency care. IgE and eosinophil analyses. Am J Respir Crit Care Med 1999; 159: 785-90.

[140] Heymann PW, Carper HT, Murphy DD, et al. Viral infections in relation to age, atopy, and season of admission among children hospitalized for wheezing. J Allergy Clin Immunol 2004; 114: 23947.

[141] Garbino J, Gerbase MW, Wunderli W, et al. Lower respiratory viral illnesses: improved diagnosis by molecular methods and clinical impact. Am J Respir Crit Care Med 2004; 170: 1197-203.

[142] Arnold JC, Singh KK, Spector SA, Sawyer MH. Undiagnosed respiratory viruses in children. Pediatrics 2008; 121: e631-7.
[143] Casiano-Colón AE, Hulbert BB, Mayer TK, Walsh EE, Falsey AR. Lack of sensitivity of rapid antigen tests for the diagnosis of respiratory syncytial virus infection in adults. J Clin Virol 2003; 28: 169-74.

[144] Falsey AR, Formica MA, Walsh EE. Diagnosis of respiratory syncytial virus infection: comparison of reverse transcription-PCR to viral culture and serology in adults with respiratory illness. J Clin Microbiol 2002; 40: 817-20.

[145] Templeton KE, Scheltinga SA, van den Eeden WC, Graffelman AW, van den Broek PJ, Claas EC. Improved diagnosis of the etiology of community-acquired pneumonia with real-time polymerase chain reaction. Clin Infect Dis 2005; 41: 345-51.

[146] Oosterheert JJ, van Loon AM, Schuurman R, et al. Impact of rapid detection of viral and atypical bacterial pathogens by real-time polymerase chain reaction for patients with lower respiratory tract infection. Clin Infect Dis 2005; 41: 1438-44.

[147] Hui DS, Woo J, Hui E, et al. Influenza-like illness in residential care homes: a study of the incidence, aetiological agents, natural history and health resource utilisation. Thorax 2008; 63: 690-7.

[148] Lieberman D, Lieberman D, Korsonsky I, et al. A comparative study of the etiology of adult upper and lower respiratory tract infections in the community. Diagn Microbiol Infect Dis 2002; 42: 21-8.

[149] Hohenthal U, Vainionpää R, Nikoskelainen J, Kotilainen P. The role of rhinoviruses and enteroviruses in community acquired pneumonia in adults. Thorax 2008; 63: 658-9.

[150] Rohde G, Wiethege A, Borg I, et al. Respiratory viruses in exacerbations of chronic obstructive pulmonary disease requiring hospitalisation: a case-control study. Thorax 2003; 58: 37-42.

[151] Qiu Y, Zhu J, Bandi V, et al. Biopsy neutrophilia, neutrophil chemokine and receptor gene expression in severe exacerbations of chronic obstructive pulmonary disease. Am J Respir Crit Care Med 2003; 168: 968-75

[152] Tan WC, Xiang X, Qui D, Ng TP, Lam SF, Hegele RG. Epidemiology of respiratory viruses in patients hospitalized with near-fatal asthma, acute exacerbations of asthma, or chronic obstructive pulmonary disease. Am J Med 2003; 115: 272-7.

[153] Gorse GJ, O'Connor TZ, Hall SL, Vitale JN, Nichol KL. Human coronavirus and acute respiratory illness in older adults with chronic obstructive pulmonary disease. J Infect Dis 2009; 199: 84757.

[154] van Gageldonk-Lafeber AB, Heijnen ML, Bartelds AI, Peters MF, van der Plas SM, Wilbrink B. A case-control study of acute respiratory tract infection in general practice patients in The Netherlands. Clin Infect Dis 2005; 41: 490-7.

[155] Malmström K, Pitkäranta A, Carpen O, et al. Human rhinovirus in bronchial epithelium of infants with recurrent respiratory symptoms. J Allergy Clin Immunol 2006; 118: 591-6.

[156] Jartti T, Waris M, Niesters HG, Allander T, Ruuskanen O. Respiratory viruses and acute asthma in children. J Allergy Clin Immunol 2007; 120: 216.

[157] Jartti T, Lee WM, Pappas T, Evans M, Lemanske RF Jr, Gern JE. Serial viral infections in infants with recurrent respiratory illnesses. Eur Respir J 2008; 32: 314-20.

[158] Jartti T, Jartti L, Peltola V, Waris M, Ruuskanen O. Identification of respiratory viruses in asymptomatic subjects: asymptomatic respiratory viral infections. Pediatr Infect Dis J 2008; 27: 1103-7.

[159] Kusel MM, de Klerk NH, Holt PG, Kebadze T, Johnston SL, Sly PD. Role of respiratory viruses in acute upper and lower respiratory tract illness in the first year of life: a birth cohort study. Pediatr Infect Dis J 2006; 25: 680-6.

[160] Khetsuriani N, Kazerouni NN, Erdman DD, et al. Prevalence of viral respiratory tract infections in children with asthma. J Allergy Clin Immunol 2007; 119: 314-21.

[161] Contoli M, Message SD, Laza-Stanca V, et al. Role of deficient type III interferon-lambda production in asthma exacerbations. Nat Med 2006; 12: 1023-6.

[162] Jartti T, Paul-Anttila M, Lehtinen P, et al. Systemic T-helper and T-regulatory cell type cytokine responses in rhinovirus vs respiratory syncytial virus induced early wheezing: an observational study. Respir Res 2009; 10: 85 .

[163] Johnston SL. Innate immunity in the pathogenesis of virus-induced asthma exacerbations. Proc Am Thorac Soc 2007; 4: 267-70.

[164] Simons E, Schroth MK, Gern JE. Analysis of tracheal secretions for rhinovirus during natural colds. Pediatr Allergy Immunol 2005; 16: 276-8. 
[165] Ratcliff RM, Chang G, Kok T, Sloots TP. Molecular diagnosis of medical viruses. Curr Issues Mol Biol 2007; 9: 87-102.

[166] Larbi A, Franceschi C, Mazzatti D, Solana R, Wikby A, Pawelec G. Aging of the immune system as a prognostic factor for human longevity. Physiology (Bethesda) 2008; 23: 64-74.

[167] Fulop T, Larbi A, Wikby A, Mocchegiani E, Hirokawa K, Pawelec G. Dysregulation of T-cell function in the elderly : scientific basis and clinical implications. Drugs Aging 2005; 22: 589-603.

[168] Holt PG, Upham JW, Sly PD. Contemporaneous maturation of immunologic and respiratory functions during early childhood: implications for development of asthma prevention strategies. J Allergy Clin Immunol 2005; 116: 16-24.

[169] Fulop T, Pawelec G, Castle S, Loeb M. Immunosenescence and vaccination in nursing home residents. Clin Infect Dis 2009; 48: 443-8.

[170] Keicho N, Elliott WM, Hogg JC, Hayashi S. Adenovirus E1A upregulates interleukin-8 espression induced by endotoxin in pulmonary epithelial cells. Am J Physiol 1997; 272: L1046-52.

[171] Yamada K, Elliott WM, Hayashi S, et al. Latent adenoviral infection modifies the steroid response in allergic lung inflammation. J Allergy Clin Immunol 2000; 106: 844-51.

[172] Meshi B, Vitalis T, Ionescu D, Elliott WM, Hayashi S, Hogg JC. Emphysematous lung destruction by cigarette smoke: effect of latent adenoviral infection. Am J Respir Cell Mol Biol 2001; 25: 1-6.

[173] Ratemales I, Elliott WM, Meshi B, et al. The amplification of inflammation in emphysema and its association with latent adenoviral infection. Am J Respir Crit Care Med 2001; 164: 46973.
[174] Kotaniemi-Syrjänen A, Vainionpää R, Reijonen TM, Waris M, Korhonen K, Korppi M. Rhinovirus-induced wheezing in infancythe first sign of childhood asthma? J Allergy Clin Immunol 2003; 111: 66-71.

[175] Lemanske RF Jr, Jackson DJ, Gangnon RE, et al. Rhinovirus illnesses during infancy predict subsequent childhood wheezing. J Allergy Clin Immunol 2005; 116: 571-7.

[176] Lehtinen P, Ruohola A, Vanto T, Vuorinen T, Ruuskanen O, Jartti $\mathrm{T}$. Prednisolone reduces recurrent wheezing after a first wheezing episode associated with rhinovirus infection or eczema. J Allergy Clin Immunol 2007; 119: 570-5.

[177] Kusel MM, de Klerk NH, Kebadze T, et al. Early-life respiratory viral infections, atopic sensitization, and risk of subsequent development of persistent asthma. J Allergy Clin Immunol 2007; 119: 1105-10.

[178] Jackson DJ, Gangnon RE, Evans MD, et al. Wheezing rhinovirus illnesses in early life predict asthma development in high-risk children. Am J Respir Crit Care Med 2008; 178: 667-72.

[179] Ruuskanen O, Lahti E, Jennings LJ, Murdoch DR. Viral Pneumonia. Lancet 2011; 377: 1264-75.

[180] Peltola VT, McCullers JA. Respiratory viruses predisposing to bacterial infections: role of neuraminidase. Pediatr Infect Dis J 2004; 23: S87-97.

[181] Herfst S, Fouchier RA. Vaccination approaches to combat human metapneumovirus lower respiratory tract infections. J Clin Virol 2008; 41: 49-52.

[182] Enjuanes L, Dediego ML, Alvarez E, Deming D, Sheahan T, Baric R. Vaccines to prevent severe acute respiratory syndrome coronavirus-induced disease. Virus Res 2008; 133: 45-62.

(C) Jartti et al.; Licensee Bentham Open.

This is an open access article licensed under the terms of the Creative Commons Attribution Non-Commercial License (http://creativecommons.org/licenses/ by-nc/3.0/) which permits unrestricted, non-commercial use, distribution and reproduction in any medium, provided the work is properly cited. 